\title{
Mid-Infrared gas sensor for pollutants: Case study, Mexico City
}

\author{
G. E. Sandoval-Romero ${ }^{1, *}$, V. Argueta-Diaz ${ }^{2}$ \\ ${ }^{1}$ Universidad Nacional Autónoma de México, Centro de Ciencias Aplicadas y Desarrollo Tecnológico, Circuito Exterior S/N, A.P. 70-186, \\ México D. F., C. P. 04510, México \\ ${ }^{2}$ Alma College, Physics Department; 614 W Superior St., Alma, MI, 48801, USA
}

Email address:

eduardo.sandoval@ccadet.unam.mx (G. E. Sandoval-Romero), arguetav@alma.edu (V. Argueta-Diaz)

\section{To cite this article:}

G. E. Sandoval-Romero, V. Argueta-Diaz. Mid-Infrared Gas Sensor for Pollutants: Case Study, Mexico City. American Journal of Modern Physics. Vol. 4, No. 1, 2015, pp. 22-25. doi: 10.11648/j.ajmp.20150401.15

\begin{abstract}
This paper analyses the feasibility of studying the composition of the suspended particles in Mexico City, using for this study, an optical method to choose the most appropriate source of emission, depending on the environmental components. The proper choice of the emission source, allows a more correct assessment of the concentration of pollutants and their characteristics, always harmful to human health. To achieve this, is used the Mie scattering calculations, which are performed for spherical particles like here are studied.
\end{abstract}

Keywords: Pollutants, Suspend Particles, Mie Efficiencies

\section{Introduction}

The effects of pollution on health are of particular interest in big urban areas like Mexico City. A particular challenge is the detection of suspended particles; $\mathrm{PM}_{10}$ andPM $\mathrm{P}_{2.5}$ suspended particles, for example, are a classification where industrial as well as organic pollutants are enclosed. The ubiquity and persistence of these particular suspended particles (they can travel hundreds of miles and be suspended for weeks) are a major health threat.

Twenty million habitants, $1200 \mathrm{~km}^{2}$ and more than four million automobiles make Mexico City one of biggest and more polluted city in the world. If we further consider the fact that Mexico City is located at 2300 meters over sea level and that it is surrounded by mountains we may start to appreciate the challenging weather conditions of this city. Added to the huge number of vehicles we found that Mexico city's gasoline has a high concentration of sulfur, i.e. 300-500 ppm, which is more than ten times the amount of sulfur found in the gasoline used in the U.S. and Europe [1, 2]. The combustion of fuel with high concentrations of sulfur not only prevents the use highly efficient filters on vehicles but it also contributes to the formation of fine particles $\left(\mathrm{PM}_{10}\right.$ and $\left.\mathrm{PM}_{2.5}\right)$, which are considered one of the most aggressive pollutant to human health. The government has proposed a program where the levels of sulfur will decrease to around $30 \mathrm{ppm}$ by 2012 . The investment to improve fuel's quality, however, is estimated between two and four billion US dollars. Such a high cost may cause delays in reaching the desired goal [2].

The pollution is not only a health problem, but it may affect also other areas as free-space optical communications (FSO). This statement can be exemplified if we consider that Mexico City has an average visibility of less than $8 \mathrm{~km} /$ year and an average temperature of 20 degrees Celsius. Therefore, the fog seen in Mexico City is caused mainly by pollution. In the literature several examples can be found where the attenuation due to scattering and absorption caused by fog and rain are analyzed [3-5]. Few examples, however, are found where the same effects caused by pollution are studied.

The effects of pollution are of particular interest urban areas like Mexico City where the presence of pollutants overcome the presence of natural fog. A particular challenge is due to the fact that pollutants are not chemically homogeneous, and therefore may have a different absorption coefficient than fog.

\section{Particle Composition}

\subsection{Kind of Suspend Particles in Mexico City}

We are interest in $\mathrm{PM}_{10}$ and $\mathrm{PM}_{2.5}$ particles (i.e. suspended particles of $10 \mu \mathrm{m}$ and $2.5 \mu \mathrm{m}$, respectively). A particular 
challenge is due to the fact that these particles are not chemically homogeneous. The absorption and scattering of an aerosol depends on the particle's size and composition. It is therefore necessary to evaluate the chemical composition and particle concentration.

Data for particle concentration of $\mathrm{PM}_{10}$ andPM 2.5 is available from the Environment Department of Mexico City, and reproduced in Fig. 1 [4]. We can see, in the before mentioned graph, that the levels of $\mathrm{PM}_{10}$ andPM $\mathrm{PM}_{2.5}$ have been decreasing steadily in the last twenty four years. However, it is important to mention that the recommended levels for $\mathrm{PM}_{10}$ andPM 2.5 have to be below $25 \mu \mathrm{g} / \mathrm{m} 3$ average/year to be safe for humans. The levels registered in Mexico City are considerable higher. Because the presence of these particles is related to the fuel's quality these levels are not expected to decrease until the sulfurs' concentration are reduced to about $30 \mathrm{ppm}$ in the available fuel for the inhabitants of the city.

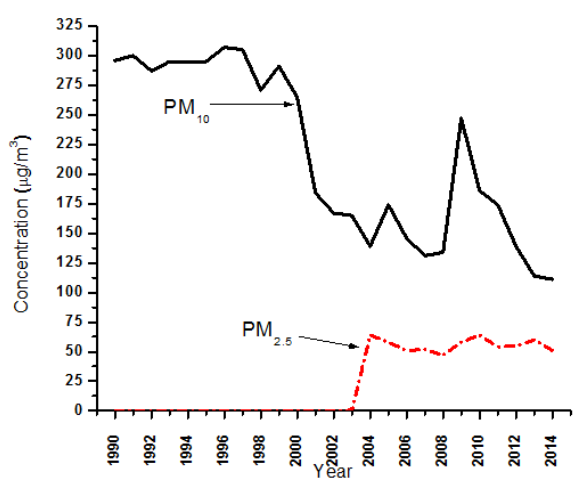

Figure 1. $P M_{10}$ and $P M_{2.5}$ concentration for the past years.

For sake of argument we will consider that the PM particles found in Mexico City are composed of sulfur and element carbon (which are the most common by-products of combustion of fuels and organic materials). It is desirable to found a wavelength that presents maximum effects of scattering and absorption for these two kinds of particles. We, therefore, assume a complex refractive index of $1.97+0.22 \mathrm{i}$ for elemental carbon and 1.57 for sulfates [4-7].

\subsection{Mie Scattering Efficiency Simulations}

We calculate the Mie efficiencies (i.e. extinction), assuming sphere particles with the before mentioned refractive indexes [8]. The efficiencies are graph with respect to the relative size $(x=2 \pi r / \lambda)$ between the particle radius $(r)$ and thewavelength ( $\lambda$ ). The evaluation results are shown in Fig. 2 [9].

From Fig. 2, we observe that there exists a range of higher extinction efficiency that goes from $x=2$ to $x=5.7$. This range, assuming a particle radius of $2.5 \mu \mathrm{m}$, corresponds to a wavelength range of 7.85 to $2.76 \mu \mathrm{m}$. In order to detect elemental carbon and sulfates we work with sources at 7.46 $\mu \mathrm{m}, 6.29 \mu \mathrm{m}, 5.45 \mu \mathrm{m}$, in order to detect sulfur dioxide $\left(\mathrm{SO}_{2}\right)$, nitrogen dioxide $\left(\mathrm{NO}_{2}\right)$ and nitrogen monoxide (NO) respectively.

This range, however, needs to be confirmed experimentally. In order to calculate a final wavelength it is necessary to determine the true chemical composition of the PM particles. This task is non-trivial, due to the fact that the pollution composition is not homogeneous.

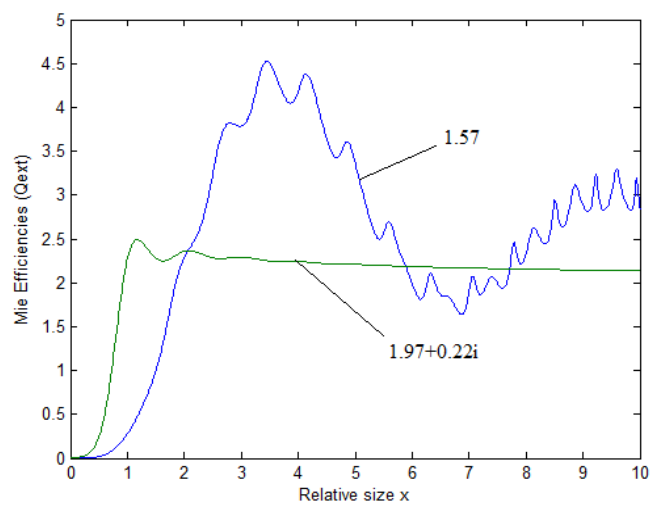

Figure 2. Extinction coefficient for elemental carbon and sulfur compound; Mie simulation for $P M_{2.5}$.

\section{Experimental Setup}

\subsection{Proposed Sensor}

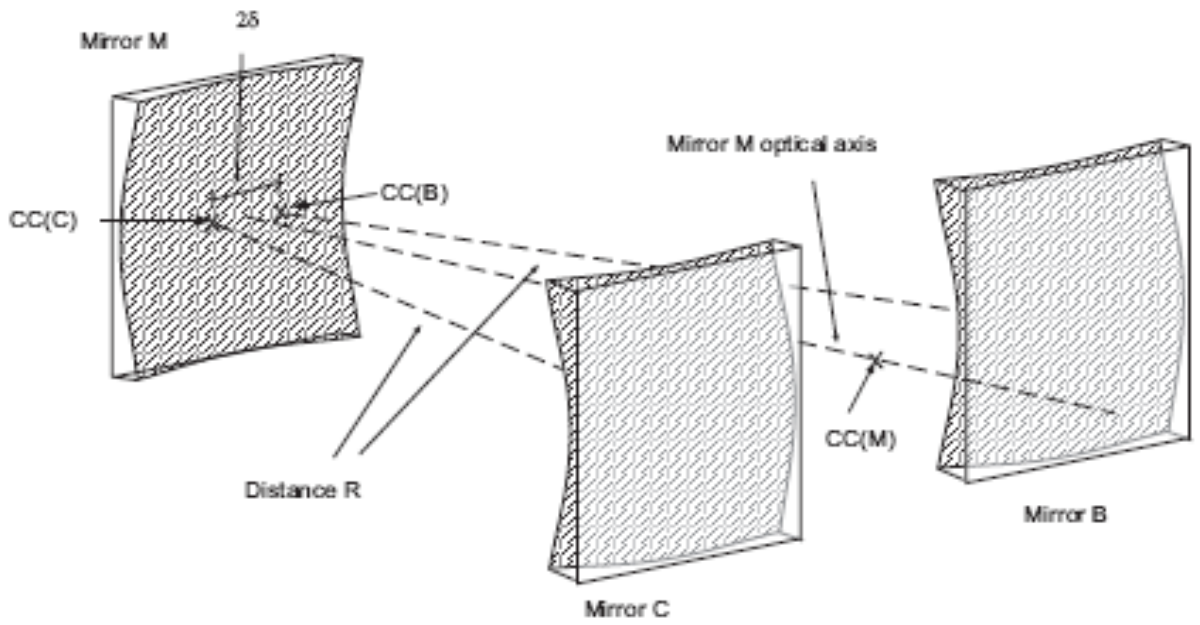

Figure 3. Basic White cell configuration. 
In order to evaluate the absorption and scattering we propose to implement a White cell-based sensor [10]. The White cell is a set of three spherical mirrors with identical radii of curvature. The beams are refocused on each bounce to spots on one of the mirrors, and several beams can bounce simultaneously inside the White cell. This system is shown in Fig. 3. A sensor based on a White cell configuration can provide of long optical paths in a small physical space.

The path of a beam through the White cell can be seen in Figure 4. Fig. 4a, shows how light enters the White cell through an input turning mirror located adjacent to mirror $\mathrm{M}$. Light is focused to a spot on the input turning mirror. Light diverging from this input spot will propagate toward mirror $\mathrm{C}$ and then be refocused by mirror $\mathrm{C}$ onto mirror $\mathrm{M}$. The input spot is located at a distance $d_{l}$ below the mirror C's center of curvature. The first image of the spot will, therefore, be located on mirror $\mathrm{M}$ at an equal distance $d_{l}$ above of C's center of curvature.

Then in Fig. 4b, we show how light is then reflected off mirror $\mathrm{M}$ and propagates toward mirror B. From here, light goes back to mirror M. Since the first image was at a distance $d_{2}$ above of mirror B's center of curvature, the second image will appear below it at the same distance $d_{2}$. From here light will propagate again towards mirror $\mathrm{C}$ and the cycle will start again. As long as the dimensions of mirror $\mathrm{B}$ and $\mathrm{C}$ are large enough to contain $99.99 \%$ of the input beam, light can be imaged back and forth between them without diffraction losses from the mirrors' edges. Therefore the losses in the system are cause only by the mirrors' reflectivity.

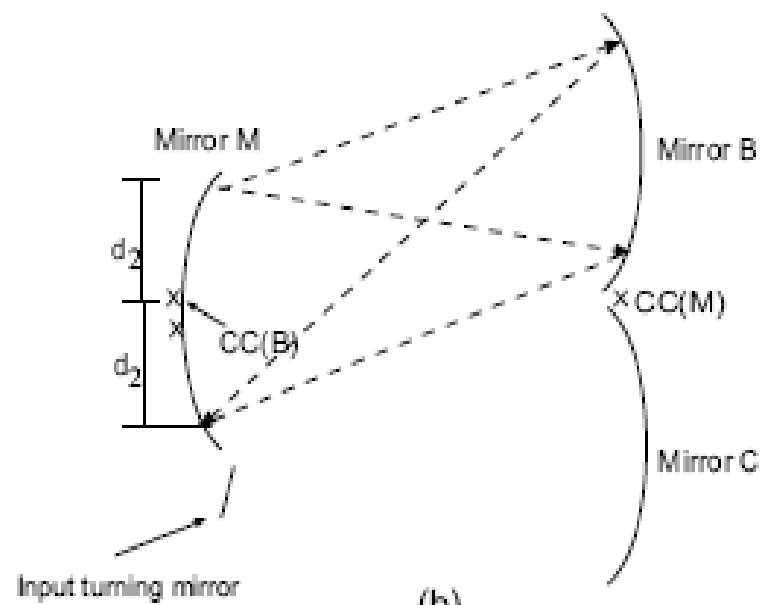

(b)

Figure 4. Top view of a White cell; a) light entering through input turning mirror images onto $M$ via mirror $C$; b) light is sent to mirror $B$ and is refocused again in $M$.

\subsection{Attenuation of Visibility}

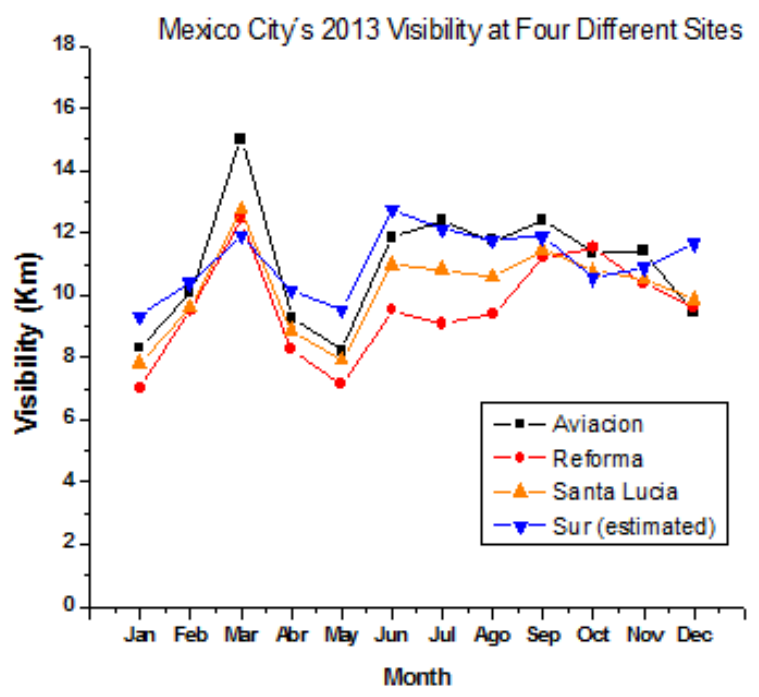

Figure 5. The visibility in Mexico City is measured by the City government. Here we present the monthly average for 2013.

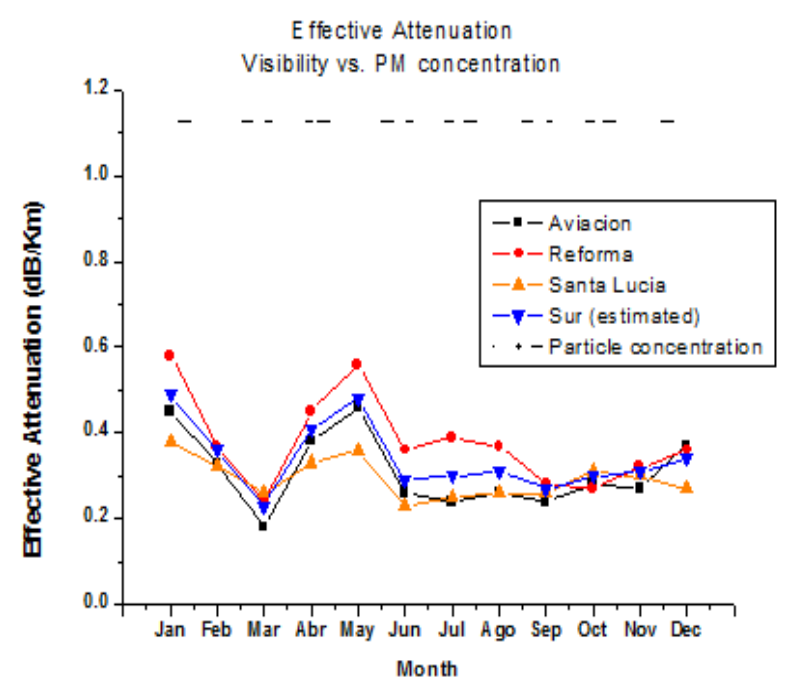

Figure 6. Comparison of the attenuation caused by the particle concentration vs. using only Beer's Law with visibility data.

The visibility measurements, Fig. 5; it can be seen that 
there is a minimum visibility of $6 \mathrm{~km}$ during January and May; are not enough to evaluate the effective attenuation that is present in Mexico City. To do a correct evaluation is necessary to take inconsideration the presence of the small particles. The effective attenuation can be estimated from the visibility measurements, or it cans also me estimated from the particle concentration and the efficiency extinction coefficient.

In Fig. 6, we compared both estimations, assuming a wavelength of $2 \mathrm{~mm}$. When we consider the presence of small particle we will have an increase in the effective attenuation. It is necessary, however, to determine the truth nature of the particle concentration, in order to confirm these results experimentally.

\section{Conclusions}

The presence of suspend particles in Mexico City not only represents a risk to human health, but it also represents a problem to free-space optical communication systems. The constant presence of suspend particles $\left(\mathrm{PM}_{10}\right.$ and $\left.\mathrm{PM}_{2.5}\right)$ increases the attenuation per kilometer in the optical link.

If we consider that more relevant pollutants are elemental carbon $(n=1.97+0.22 \mathrm{i})$ and sulfur compounds $(n=1.57)$ then we will have a transmission maximum extinction window between $7.85 \mu \mathrm{m}$ and $2.76 \mu \mathrm{m}$.

We propose to evaluate the extinction ration of three beams with $7.46 \mu \mathrm{m}, 6.29 \mu \mathrm{m}$, and $5.45 \mu \mathrm{m}$ wavelengths in order to detect, in order to detect $\mathrm{SO}_{2}, \mathrm{NO}_{2}$ and $\mathrm{NO}$ particles, respectively. The system is based on the white cell, which provides of long optical paths in a reduced physical space.

\section{Acknowledgements}

This work was supported by the UNAM-PAPIIT (IT101712). Dr. Argueta-Diaz acknowledges support from Alma College's Professional Development Fund.

\section{References}

[1] "Calidad del aire en la Ciudad de México, Informe 2011; 25 años de monitoreo atmosférico 1986-2011", Secretaria de Medio Ambiente, Gobierno del Distrito Federal, 2012.[On line]:

http://www.sedema.df.gob.mx/flippingbook/informe_anual_ca lidad_aire_2011.pdf

[2] Mario Molina, "Propuesta para Limpiar el Aire en México en 10 años, Reporte del Taller sobre la Contaminación del Aire en México", Ciudad de México, 13 abril 2004; The Internacional Council of CleanTransportation,2004.[On line]:http://www.nrdc.org/laondaverde/international/files/Mexi co_diesel_report.pdf

[3] M. T. Morandi, T. H. Stock, C. F. Contant, "A comparative study of respirable particulate microenvironmental concentrations and personal exposures", Environ. Monit. Assess., vol. 10(2), pp. 105-122, 1988.

[4] V. Kukshya, T. S. Rappaport, H. Izadpanah, G. Tangonan, R. A. Guerrero, J. K. Mendoza, B. Lee, "Free-space optics and high-speed RF for next generation networks propagation measurements," IEEE $56^{\text {th }}$,vol. 1,pp. 616-620, Sept. 2002.[Vehicular Technology Conference, 2002. Proceedings. VTC 2002-Fall].

[5] "Informe mensual de la calidad del aire en la zona metropolitana del Valle de México", Año 12, Núm. 135, Marzo 2014; Secretaría del Medio Ambiente, Gobierno del Distrito Federal.[On line]: http://www.sma.df.gob.mx/sma/////links/download/biblioteca/ informes_ejecutivos_simat/informe_ejecutivo2014mar.pdf

[6] E. Leitgeb, J. Bregenzer, P. Fasser, M Gebhart, "Free space optics -extension to fiber-networks for the 'Last Mile'," 2002 IEEE/LEOS Annual meeting conference proceedings, vol. 2, pp. 459-460, Nov. 2002 [The 15th Annual Meeting of the Lasers and Electro-Optics Society].

[7] G. Schkolnik, D. Chand, A. Hoffer, M.O. Andreae, C. Erlick,E. Swietlicki, Y. Rudich, "Constraining the density and complex refractive index of elemental and organic carbon in biomass burning aerosol using optical and chemical measurements", Atmos. Environ., vol. 41(5),pp. 1107-1118, 2007.

[8] I. W. Sudiarta, P. Chylek, "Mie scattering efficiency of a large spherical particleembedded in an absorbing medium", J. Quant. Spectrosc. Radiat. Transf.,vol. 70, pp. 709-714, 2001.

[9] H.C. van de Hulst, "Light scattering by Small Particles", Dover Publications, Inc. New York, 1981.

[10] B. L. Anderson, V. Argueta-Diaz, F. Abou-Galala, G. Radhakrishnan, R. J. Higgins, "Optical cross connect switch based on tip/tilt micromirrors in a white cell," IEEE J. Sel. Top. Quantum Electron.,vol. 9(2), pp. 579-593, 2003. 